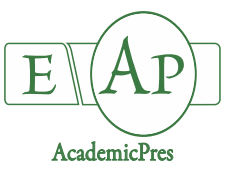

Romeilah RM et al. (2021)

Notulae Botanicae Horti Agrobotanici Cluj-Napoca

Volume 49, Issue 1, Article number 12233

DOI: $10.15835 /$ nbha 49112233

Research Article

\title{
Antioxidant and cytotoxic activities of Artemisia monosperma L. and Tamarix aphylla L. essential oils
}

\author{
Ramy M. ROMEILAH ${ }^{1,3}$, Hossam S. EL-BELTAGI ${ }^{2,3 *}$, \\ Emad A. SHALABY ${ }^{3}$, Kareem M. YOUNES ${ }^{4,5}$, Hani EL MOLL ${ }^{1}$, \\ Saravanan RAJENDRASOZHAN ${ }^{1}$, Heba I. MOHAMED ${ }^{6}$ \\ ${ }^{1}$ Hail University, College of Science, Department of Chemistry, Hail, Saudi Arabia; r.romeilah@uoh.edu.sa; \\ h.elmoll@uoh.edu.sa; s.rajendrasozhan@uoh.edu.sa \\ ${ }^{2}$ King Faisal University, College of Agriculture and Food Sciences, Agricultural Biotechnology Department, P.O. Box 420, Al-Ahsa \\ 31982, Saudi Arabia; helbeltagi@kfu.edu.sa (*corresponding author) \\ ${ }^{3}$ Cairo University, Faculty of Agriculture, Department of Biochemistry, Giza, 12613,Egypt; dremad2009@yahoo.com \\ ${ }^{4}$ Hail University, College of Pharmacy, Department of Pharmaceutical Chemistry, Hail, Saudi Arabia; k.younes@uoh.edu.sa \\ ${ }^{5}$ Cairo University, Faculty of Pharmacy, Department of Analytical Chemistry, Cairo, Egypt \\ ${ }^{6}$ Ain Shams University, Faculty of Education, Biological and Geological Sciences Department, Cairo, Egypt; \\ hebaibrahim79@gmail.com
}

\begin{abstract}
Essential (volatile) oil from leaves of Artemisia monosperma L. belonging to family Asteraceae, and aerial parts of Tamarix aphylla L. (Athel) belonging to family Tamaricaceae were collected from the desert of Ha'il region, northern region of Saudi Arabia, hydro distilled by Clevenger apparatus and analysed by means of GC-MS techniques. Antioxidant activities of essential oils of $A$. monosperma and T. aphylla compared with ascorbic acid and butylated hydroxytoluene (BHT) as reference antioxidant compound were determined by method of DPPH radical scavenging assay and ABTS assay. In vitro screening of potential cytotoxicity of essential oils was also evaluated against human promyelocytic leukaemia cell lines (HL60 and NB4). The GC/MS analysis of $A$. monosperma essential oil resulted in identification of 61 components predominated mainly by $\beta$-Pinene as principal component $(29.87 \%)$ and $T$. aphylla resulted in identification of 37 components of essential oil predominated mainly by 6,10,14- trimethyl-2-pentadecanone $(21.43 \%)$ as principal component. Antioxidant activity as 2,2-diphenyl-1-picrylhydrazyl (DPPH) radical scavenging and 2,2 -azino-bis (3-ethylbenzothiazoline-6-sulfonic acid (ABTS) increased with increasing essential oil concentrations of $A$. monosperma and $T$. aphylla $\left(25,50,75,100\right.$ and $\left.200 \mu \mathrm{g} \mathrm{mL}^{-1}\right)$. The most pronounced increases detected in the high concentrations of the two essential oils. Biologically, essential oil extracts exhibited cytotoxicity effects in dose dependent manner against human promyelocytic leukaemia cell lines (HL60 and NB4). In conclusion, A. monosperma and T. aphylla essential oils could be valuable source for cytotoxic agents with high safety and selective cytotoxicity profiles.
\end{abstract}

Keywords: antioxidant activity; Artemisia monosperma; cytotoxic activity; essential oil; Tamarix aphylla

Received: 23 Jan 2021. Received in revised form: O7 Feb 2021. Accepted: 10 Feb 2021. Published online: 11 Feb 2021.

From Volume 49, Issue 1, 2021, Notulae Botanicae Horti Agrobotanici Cluj-Napoca journal will use article numbers in place of the traditional method of continuous pagination through the volume. The journal will continue to appear quarterly, as before, with four annual numbers. 


\section{Introduction}

In the Ancient history there were used plants and other natural products for a range of purposes such as food, decorations, clothing, soaps, cosmetics, and medicinal uses (Pandey and Tripathi, 2011). Essential oilbearing plants were observed to be useful in traditional medicine for treatment and/or prevention of various diseases (Mohamed et al., 2018a, b; El-Beltagi et al., 2018; 2019a, b). These plants recently produced a total yearly output of oils to above 45000 tones, produced by more than 100 precious essential oils used in market terms, as antibacterial, antifungal, antiviral, antioxidant, anti-inflammatory, cytotoxic, and many other effects (Sikka and Bartolome, 2018; El-Beltagi et al., 2020a, b; Dawi et al., 2021). Vast quantities of them are also used for the smell in perfumery field as well as in the pharmaceutical and food sector (Malik, 2018).

Furthermore, aromatherapy, a major complementary and alternative medicine industry is very commonly used in essential oils (CAM). It is used for a series of diseases for treatment, it is utilized in variety of activities, including inhalations, oral administrations, mouthwashes, and even trans-dermal processes (Bae et al., 2018). However, essential oils contain various chemical classes such as terpenoids, alcohols, aldehydes, ketones, oxides, phenolic ethers, and hydrocarbons (Aly et al., 2013; Dhif et al., 2016; Hamed et al., 2019).

Antioxidants are active ingredients capable of preventing or postponing process of oxidation and autoxidation by reducing generation of deleterious free radicals (Mohamed et al., 2009; Abdel-Rahim and ElBeltagi, 2010; Abd El-Rahman et al., 2012; El-Beltagi et al., 2017; Abd El-Maksoud et al., 2018). These radicals can cause severe organ damage to cells, tissues, and even entire organs in some circumstances, which can, as a result, cause lethal diseases (Shallan et al., 2010a, b; Apostolova and Victor, 2015). Many phytochemicals and other microelements like ascorbic acid, tocopherol, carotenoids, flavonoids, anthocyanins, have antioxidant properties (Helmi and Mohamed, 2016; Guo et al., 2017; Akladious and Mohamed, 2017). They based their mechanism of action, however, mostly on DNA oxidation inhibition, which prevents lipid oxidation, build up of atherosclerotic plaques, and low-density lipoprotein oxidation (LDL), preventing the risks of various types of cancer and different cardiovascular diseases (Reis et al., 2016; Afify and El-Beltagi, 2011; Afify et al., 2012).

Therapeutic, cosmetic, and aromatic properties of Asteraceae family are recognized. The key uses of this family are astringent, cholesteric, anti-haemorrhagic, antimicrobial, antioxidant, diuretics, analgesics and antispasmodic (Fabri et al., 2011; Maham et al., 2014). Asteraceae family is indented with essential oiled plants in plant kingdom, in which Artemisia genus takes its lead for bio-prospection. A. monosperma Del is a bushy, leafy tree with long small leaves containing scattered hair (Abad et al., 2012). In Saudi Arabia, it is famous, where it goes under the local name of Aader or Selikah (Khan et al., 2012). The flower spikes have tiny green bracts and round green bud-like flowers. It is a perennial fragrant plant that grows high in the Deserts of Arabia, up to 1 meter in height (Khan et al., 2012). A. monosperma is also found in the desert of other Arabian countries such as Iraq, Kuwait, Egypt, and Saudi Arabia (Khan et al., 2012). Most of the species have strong scents and bitter tastes, that impede the herbivory, because of presence of terpenoids and sesquiterpene lactones (Bora and Sharma, 2011). A test was carried out in laboratory in essential oils and chemical components of many different species of Artemisia to avoid oxidative harm by preventing or loosening free radicals or reactive species of oxygen. They have proven to be an alternative to synthetic antioxidants (Singh et al., 2015).

Tamaricaceae is a large family comprising of several genera, many of whose are tiny shrubs and trees described as exotic, deciduous, or invasive. Previous studies have detected presence of different types of secondary metabolites in plant extract of several genera of Tamaricaceaelike flavonoids (El Ansari et al., 1976), phenolics (Souliman et al., 1991), tannins (Orabi et al., 2015), and alkaloids (Yusufoglu et al., 2015). Tamarix aphylla is one of species that comes from this family that lives naturally in Asia, North Africa, south-eastern Europe and Saudi Arabia (Al Sobeai, 2018; Jasiem et al., 2019). Several countries have used T. aphylla in traditional medicine. Its leaves were used for wounds and abscess healing, as astringent, and for rheumatism and joint pain (Marwat et al., 2009; Mahfoudhi et al., 2016). T. aphylla extract caused inhibition of insect growth because of presence of phenolic compounds like ellagic acid, tannin and may be used as an insecticidal activity (Klocke et al., 1985). Aphyllin is also the isolated isoferulic acid derivative, which shows separate 
operation for radical scavenging and increases viability of human keratinocytes (Nawwar et al., 2009). In Saudi Arabia, alcohol extract of $T$. aphylla leaves have antioxidant, anti-inflammatory, and wound-healing functions because of the existence of active phytochemical compounds such as flavonoids or polyphenols (Yusufoglu and Alqasoumi, 2011).

Many studies have examined the potential roles of various $T$. aphylla extracts in prevention and/or treatment of many ailments (Mahfoudhi et al., 2016; Qadir et al., 2014) however, there has been very little research focusing on studying the volatile essential oil composition or assessing the antiproliferative effects against certain cancer cell lines. So that the present study aimed to essential oil hydro distilled from leaves of $A$. monosperma, and aerial parts of T. aphylla L. wild grown in desert of Ha'il region, northern region of Saudi Arabia was analysed by gas chromatography-mass spectrometry (GC-MS) and the antioxidant activity was measured. In vitro cytotoxic activities of aqueous extract against human promyelocytic leukaemia cell lines (HL60 and NB4) were also assessed.

\section{Materials and Methods}

\section{Plant material}

The leaves of Artemisia monosperma belonging to family Asteraceae, and aerial parts of Tamarix aphylla $L$ (Athel) belonging to family Tamaricaceae were collected from desert of Ha'il region, northern region of Saudi Arabia. Dr. Mohamed Osama El-Segaee, Professor of Taxonomy, Faculty of Agriculture, Cairo University, kindly named plant samples.

\section{Essential oil extraction}

Five hundred grams of Artemisia monosperma dried leaves and dried aerial parts of Tamarix aphylla were hydro distilled in Clevenger type apparatus for $4 \mathrm{~h}$ and following standard procedure described in literature (European Pharmacopoeia, 2005). The essential oils were dried over anhydrous sodium sulphate, stored in a dark glass bottle, and kept at $4{ }^{\circ} \mathrm{C}$ until analysis and amount of oil obtained from plant material was calculated as:

$$
\text { Oil }(\% v / w)=\frac{\text { Observed volume of oil }(m L)}{\text { Weight of sample }(g)} \times 100
$$

\section{GC/MS analysis of essential oils}

Essential oils were analysed by GC-MS according to Adams (1989). The GC/MS analysis was performed on rmoquest-Finnigan Trace GC-MS equipped with DB-5 (5\% phenyl) methylpolysiloxane column $(60 \mathrm{~m} \backslash 0.25 \mathrm{~mm}$ i.d., film thickness $0.25 \mu \mathrm{m})$. The injection temperature was $220{ }^{\circ} \mathrm{C}$ and oven temperature was raised from $40^{\circ} \mathrm{C}(3 \mathrm{~min}$ hold $)$ to $250^{\circ} \mathrm{C}$ at a rate of $5^{\circ} \mathrm{C} / \mathrm{min}$, then held at $250^{\circ} \mathrm{C}$ for $2 \mathrm{~min}$; transfer line temperature was $250^{\circ} \mathrm{C}$. One microliter of the sample was injected and helium was used at flow rate of $1.0 \mathrm{ml} / \mathrm{min}$ as carrier gas. Mass spectrometer with ionizing voltage of $70 \mathrm{eV}$ was scanned over 40 to 500 $\mathrm{m} / \mathrm{z}$ and identification was based on standard mass library used by National Institute of Standards and Technology (NIST Version 2.0) and Wiley libraries to detect the possibilities of essential oil components.

\section{DPPH free radical scavenging assay}

Radical scavenging activity of plant essential oils against stable DPPH radical was determined spectrophotometrically (Brand-Williams et al., 1995). On UV/visible light spectrophotometer, colorimetric shifts (from deep-violet to light-yellow) were calculated at $517 \mathrm{~nm}$ when DPPH• was reduced. In terms of hydrogen donation or radical scavenging potential, antioxidant activity of essential oils was calculated using stable radical DPPH. Fifty microliters of different concentrations $\left(25,50,75,100\right.$ and $\left.200 \mu \mathrm{g} \mathrm{mL}^{-1}\right)$ of essential 
oils containing 5, 10,20, 40 and $60 \mu \mathrm{g} \mathrm{mL}^{-1}$ of dimethyl sulphoxide (DMSO) as well as ascorbic acid and butylated hydroxytoluene (BHT) (as standard antioxidant compounds) were placed in suitable tubes and $5 \mathrm{~mL}$ of $0.004 \%$ methanolic solution of $\mathrm{DPPH}^{\bullet}$ was added to each tube to give final concentrations of $25,50,75,100$ and $200 \mu \mathrm{g} \mathrm{mL}^{-1}$ ). Absorbance measurements commenced immediately. The decrease in absorbance at $517 \mathrm{~nm}$ was determined after $1 \mathrm{~h}$ for all samples. Methanol was used to zero the spectrophotometer. Absorbance of DPPH radical without antioxidant, i.e. the control, was measured. Care was taken to minimize DPPH radical stock solution's loss of free radical activity. Radical scavenging activity percentage inhibition was calculated in accordance with formula of Yen and Duh (1994):

DPPH scavenging effect $\left.(\%)=\left(A_{\mathrm{C}(\mathrm{o})}-A_{\mathrm{A}(\mathrm{t})}\right) / A_{\mathrm{C}(\mathrm{o})}\right) \times 100$

Where $A_{\mathrm{C}(\mathrm{o})}$ is absorbance of control at $\mathrm{t}=0 \mathrm{~min}$ and $A_{\mathrm{A}(\mathrm{t})}$ is absorbance of antioxidant at $\mathrm{t}=1 \mathrm{~h}$.

Simple regression analysis was used to derive $\mathrm{IC}_{50}$ value (corresponding to concentration of $50 \%$ of inhibition).

\section{ABTS radical scavenging activity}

With some modifications, ABTS radical scavenging activity was determined according to technique described by Re et al. (1999). ABTS solution was prepared by dissolving ABTS (2,20-azino-bis (3ethylbenzothiazoline-6-sulphonic acid) in water to $7 \mathrm{mM}$ concentration. ABTS radical cation $\left(\mathrm{ABTS}^{\bullet+}\right)$ was also developed by reacting with $2.45 \mathrm{mM}$ potassium persulfate (final concentration) ABTS solution and allowing mixture to stand in dark for 12-16 h before use at room temperature. Then, absorbance of final ABTS radical solution was adjusted to 0.7 at $734 \mathrm{~nm}$. The essential oils with concentrations of $25,50,75,100,200 \mu \mathrm{g}$ $\mathrm{mL}^{-1}$ as well as ascorbic acid and butylated hydroxytoluene (BHT) standards with concentrations of 5, 10, 20, 40 and $60 \mu \mathrm{g} \mathrm{mL}^{-1}$ were combined with stabilized radical solution and incubated at $30^{\circ} \mathrm{C}$. After $30 \mathrm{~min}$, the absorbances were spectrophotometrically measured at $734 \mathrm{~nm}$. Percentage inhibition of radical scavenging activity was calculated according to formula of Yen and Duh (1994):

ABTS scavenging effect $(\%)=\left(\left(A_{\mathrm{C}(\mathrm{o})}-A_{\mathrm{A}(\mathrm{t})}\right) / A_{\mathrm{C}(\mathrm{o})}\right) \times 100$

Where $A_{\mathrm{C}(\mathrm{o})}$ is absorbance of control at $\mathrm{t}=0 \mathrm{~min}$ and $A_{\mathrm{A}(\mathrm{t})}$ is absorbance of antioxidant at $\mathrm{t}=1 \mathrm{~h}$.

Simple regression analysis was used to derive the $\mathrm{IC}_{50}$ value (corresponding to concentration of $50 \%$ of inhibition).

\section{Cytotoxic activity of essential oils}

Human promyelocytic leukaemia cell lines (HL60 and NB4) obtained from American Type Culture Collection (ATCC). All these cells were maintained in RPMI-1640 supplemented with 10\% FBS, 2 mmol/L $\mathrm{L}$ - glutamine, penicillin $(100 \mathrm{U} / \mathrm{ml})$, and streptomycin $\left(100 \mathrm{mg} \mathrm{mL}^{-1}\right)$ in a humidified atmosphere of $5 \% \mathrm{CO}_{2}$ at $37^{\circ} \mathrm{C}$ for $24 \mathrm{~h}$ after that the cell counts were determined. After this period the cell viability was evaluated using trypan blue technique. The viability percentage of cancer cells were measured by modified cytotoxic trypan blue-exclusion technique of Bennett et al. (1976). 2 × 105 cells/ml were seeded on 96-well plate prior to assay and then viability percentage of cancer cells was determined by treatment with different amounts of essential oils examined to give final concentrations of 25, 50,75, 100, $200 \mathrm{ug} \mathrm{ml}^{-1}$. The plate was incubated at $37{ }^{\circ} \mathrm{C}$ for $24 \mathrm{~h}$ under $5 \% \mathrm{CO}_{2}$. Final volume in each experiment was made up to $100 \mu \mathrm{l}$ with media containing $1 \%$ dimethyl sulphoxide (DMSO). Control cells were treated with equivalent amount of vehicle DMSO and then an equal volume of $0.4 \%$ trypan blue was added to each experiment and left to stand for 5 minutes at room temperature. $10 \mu \mathrm{l}$ of stained cells were added in a hemocytometer slide and number of viable (unstained) and dead (stained) cells were counted. Each experiment was carried out in triplicate. Percentage of viable cells is [number of viable cells] divided by total number of [dead plus viable cells], multiplied by 100 . 
$\%$ viable cells $=100 \times[$ live cells $] /[$ dead + live cells $]$

The percentage of dead cells of each cell line were plotted against essential oil concentrations to obtain the " $50 \%$ lethal concentration" IC $\mathrm{C}_{50}$, defined as essential oil concentration necessary to cause $50 \%$ death.

\section{Statistical analysis}

Statistical analyses were done using SPSS (version 25) program. Mean and standard error were descriptive measures of quantitative data using analysis of variance test (ANOVA) for independent samples. Pvalues $<0.05$ were considered significant.

\section{Results and Discussion}

\section{Oil composition by $G C / M S$}

The hydro distillation of $A$. monosperma leaves yield oil about $1.04 \%(\mathrm{v} / \mathrm{w})$. The essential oils were analysed by GC/MS for determination of their components and results are given in Tables 1 as a relative peak area of each constituent. As shown in Table 1, GC-MS analysis of $A$. monosperma essential oil resulted in identification of 61 components predominated mainly by $\beta$-Pinene as principal component $(29.87 \%)$, $\alpha$ Terpinolene (8.56\%), Bornyl acetate (7.63\%), cis- $\beta$-Ocimene $(7.11 \%)$ and Limonene $(5.65 \%)$ as major ones. Oil composition of present study was similar to results of Khan et al. (2012) who found that $\beta$-pinene and $\alpha$ terpinolene prevailed among components of Saudi leaf and stem essential oils. Oil composition determined in present study differed significantly from those reported earlier. Soliman (2007) found that propenoic acid, 3phenylethyl ester, 2-pinene-4-one, $p$-cymene and geraniol as major constituents of $A$. monosperma oil. While Saleh (1985) observed that 3-methyl-3-phenyl-1,4-pentadiyne and capillen as major constituents of $A$. monosperma leaf oil. Artemisia scoparia, Artemisia judaica and Artemisia sieberi growing in northern region of Saudi Arabia were investigated regarding their volatile oil contents. Yield of oil ranged between 0.30 and $0.41 \%$, (w/w). A. monosperma showed highest number of compounds with 30 components representing $93.78 \%$ of oil composition. Nevertheless, $A$. judaica showed the lowest number of compounds with just 16 components containing $87.47 \%$ of essential oil. A. scoparia and A. sieberi are both composed of 17 components, comprising 97.14 and $94.2 \%$ of total oil composition. A. sieberi and A. judaica were dominated by spathulenol (30.42 and $28.41 \%$, respectively). For $A$. monosperma, butanoic acid (17.87\%) was a major component (Guetat et al., 2017).

The hydro distillation of T. aphylla aerial parts yield oil about $0.22 \%(\mathrm{v} / \mathrm{w})$. The essential oils were analysed by GC/MS for determination of their components and results are given in Table 2 as a relative peak area of each constituent. As shown in Table 2, the GC-MS analysis of T. aphylla essential oil resulted in identification of 37 components predominated mainly by 6,10,14-trimethyl-2-pentadecanone as principal component (21.43\%), 1,8-cineole (15.75\%), ledol (8.24\%), $\alpha$-pinene (7.31\%), and trans-pinocarveol (6.81\%) as major ones. Similar findings were reported by Alhourani et al. (2018) who found that GC-MS analysis of $T$. aphylla EO revealed its richness in nonterpenoid nonaromatic hydrocarbon (52.39\%), with predominance of 6,10,14-trimethyl-2-pentadecanone as principal component.

Different compositions of the essential oil from different Tamarix species were also reported in literature. As described by Orfali (2009), bicyclo[2.2.2]octan-2-one was found to be the major compound (46.09\%) in T. nilotica of Saudi Arabia. Hexadecanoic acid methyl ester was reported as major principle in $T$. chinensis fruit (Mahemuti et al., 2015). Hexadecanoic acid (in aerial parts and stems), 2,4-nonadienal (in flowers), and germacrene D (in leaves) were, however, reported as majors of T. boveana (Saidana et al., 2008). Like in T. chinensis, nonaromatic hydrocarbons approached abundant group of T. aphylla aerial sections, while fatty acids and fatty esters are majors in $T$. boveana leaves. On the other hand, among terpenes, oxygenated and hydrocarbon sesquiterpenes are prevalent in T. aphylla and T. boveana (Saïdana et al., 2008) respectively. 
Table 1. Chemical composition of $A$. monosperma leaves essential oils

\begin{tabular}{|c|c|c|c|c|}
\hline No. & RT & RI & Compound name & Area sum \% \\
\hline 1 & 4.55 & 921 & $\alpha$-Thujene & 0.21 \\
\hline 2 & 5.11 & 935 & $\alpha$-Pinene & 3.98 \\
\hline 3 & 5.34 & 944 & Camphene & 0.06 \\
\hline 4 & 5.56 & 974 & Sabinene & 4.14 \\
\hline 5 & 5.87 & 992 & $\beta$-Pinene & 29.87 \\
\hline 6 & 5.98 & 997 & $\beta$-Myrcene & 0.32 \\
\hline 7 & 6.07 & 1001 & Mesitylene & 0.07 \\
\hline 8 & 6.19 & 1004 & $\alpha$-Phellandrene & 0.11 \\
\hline 9 & 6.57 & 1019 & $\alpha$-Terpinene & 0.53 \\
\hline 10 & 6.84 & 1023 & p-Cymene & 0.09 \\
\hline 11 & 7.01 & 1029 & Limonene & 5.65 \\
\hline 12 & 7.17 & 1032 & $\gamma$-Terpinene & 0.37 \\
\hline 13 & 7.22 & 1045 & trans- $\beta$-Ocimene & 2.13 \\
\hline 14 & 7.31 & 1049 & cis- $\beta$-Ocimene & 7.11 \\
\hline 15 & 7.66 & 1052 & $\alpha$-Terpinolene & 8.56 \\
\hline 16 & 8.29 & 1079 & cis-Sabinene hydrate & 5.32 \\
\hline 17 & 8.61 & 1110 & Linalool & 1.34 \\
\hline 18 & 9.04 & 1123 & p-Mentha-1,3,8-triene & 0.04 \\
\hline 19 & 10.21 & 1127 & $\beta$-Thujone & 0.08 \\
\hline 20 & 10.96 & 1142 & trans-p-Menth-2-en-1-ol & 0.09 \\
\hline 21 & 11.56 & 1155 & Camphor & 1.12 \\
\hline 22 & 12.07 & 1186 & Terpinen-4-ol & 1.12 \\
\hline 23 & 12.23 & 1192 & p-Cymene-8-ol & 1.61 \\
\hline 24 & 12.32 & 1197 & $\alpha$-Terpineol & 1.11 \\
\hline 25 & 12.89 & 1225 & Fenchyl acetate & 0.06 \\
\hline 26 & 13.02 & 1229 & Carvotanacetone & 0.12 \\
\hline 27 & 13.57 & 1244 & Piperitone & 0.21 \\
\hline 28 & 14.11 & 1278 & Bornyl acetate & 7.63 \\
\hline 29 & 14.33 & 1295 & Thymol & 2.01 \\
\hline 30 & 14.88 & 1307 & Carvacrol & 0.13 \\
\hline 31 & 15.34 & 1335 & Piperitenone & 0.04 \\
\hline 32 & 15.87 & 1349 & $\alpha$-Terpenyl acetate & 0.09 \\
\hline 33 & 15.96 & 1353 & Citronellyl acetate & 0.18 \\
\hline 34 & 16.65 & 1390 & $\beta$-Elemene & 0.13 \\
\hline 35 & 17.02 & 1409 & Cinerone & 0.08 \\
\hline 36 & 17.55 & 1431 & Davana ether & 0.03 \\
\hline 37 & 18.03 & 1456 & $\beta$-Vinylnaphthalene & 3.67 \\
\hline 38 & 18.22 & 1464 & $\alpha$-Humulene & 0.25 \\
\hline 39 & 19.00 & 1485 & Germacrene D & 0.15 \\
\hline 40 & 19.22 & 1496 & $\alpha$-Curcumene & 0.08 \\
\hline 41 & 19.75 & 1502 & cis-Methyl isoeugenol & 0.05 \\
\hline 42 & 20.23 & 1509 & Bicyclogermacrene & 0.06 \\
\hline 43 & 20.86 & 1512 & $\alpha$-Muurolene & 0.16 \\
\hline 44 & 21.26 & 1516 & Citronellyliso-valerate & 0.07 \\
\hline 45 & 21.87 & 1519 & Spathulenol & 0.07 \\
\hline 46 & 22.07 & 1521 & Shyobunone & 0.03 \\
\hline 47 & 22.88 & 1529 & $\gamma$-Cadinene & 0.09 \\
\hline 48 & 23.45 & 1532 & $\delta$-Cadinene & 0.12 \\
\hline 49 & 23.89 & 1534 & $\alpha$-Cadinene & 0.04 \\
\hline
\end{tabular}


Romeilah RM et al. (2021). Not Bot Horti Agrobo 49(1):12233

\begin{tabular}{|c|c|c|c|c|}
\hline No. & RT & RI & Compound name & Area sum \% \\
\hline 50 & 24.01 & 1548 & Nerolidol-epoxyacetate & 0.23 \\
\hline 51 & 24.73 & 1563 & Longicamphenylone & 2.08 \\
\hline 52 & 25.11 & 1577 & Spathulenol & 0.91 \\
\hline 53 & 25.43 & 1583 & Neryl isovalerate & 0.07 \\
\hline 54 & 25.87 & 1594 & Davanone & 1.06 \\
\hline 55 & 27.86 & 1643 & $\alpha$-Muurolol & 0.06 \\
\hline 56 & 28.96 & 1654 & $\beta$-Eudesmol & 0.12 \\
\hline 57 & 29.07 & 1659 & $\alpha$-Eudesmol & 0.42 \\
\hline 58 & 29.76 & 1663 & trans-Caryophyllene & 0.21 \\
\hline 59 & 30.23 & 1666 & $\alpha$-Cadinol & 0.23 \\
\hline 60 & 31.08 & 1689 & Geranyl tiglate & 0.08 \\
\hline 61 & 31.97 & 1798 & Farnesyl acetate & 97.08 \\
\hline \multicolumn{5}{|r|}{ Total identified } \\
\hline
\end{tabular}

$\mathrm{RT}=$ Retention time; RI= Retention index; Area sum \%; Values were expressed as [area percentage]

Table 2. Chemical composition of T. aphylla aerial parts essential oils

\begin{tabular}{|c|c|c|c|c|}
\hline No. & $\mathrm{RT}$ & RI & Compound name & $\%$ content \\
\hline 1 & 5.04 & 935 & A-pinene & 7.31 \\
\hline 2 & 5.74 & 992 & $\beta$-pinene & 1.01 \\
\hline 3 & 7.32 & 1005 & 1,8-cineole & 15.75 \\
\hline 4 & 7.99 & 1023 & O-cymene & 0.82 \\
\hline 5 & 8.45 & 1032 & $\gamma$-terpinene & 0.57 \\
\hline 6 & 8.94 & 1052 & Terpinolene & 1.51 \\
\hline 7 & 9.87 & 1109 & $\alpha$-thujone & 2.77 \\
\hline 8 & 10.43 & 1136 & Trans-pinocarveol & 6.81 \\
\hline 9 & 11.58 & 1198 & Fenchyl alcohol & 0.61 \\
\hline 10 & 13.96 & 1215 & $\beta$-cyclocitral & 0.44 \\
\hline 11 & 14.66 & 1223 & Cis-carveol & 1.29 \\
\hline 12 & 16.98 & 1244 & Carvone & 0.61 \\
\hline 13 & 18.05 & 1281 & Ledene & 0.22 \\
\hline 14 & 19.65 & 1405 & Dodecanal & 0.64 \\
\hline 15 & 21.76 & 1440 & Neryl acetone & 1.43 \\
\hline 16 & 22.07 & 1446 & Aromadendrene & 0.55 \\
\hline 17 & 24.35 & 1465 & $\beta$-ionone & 3.55 \\
\hline 18 & 25.88 & 1507 & Farenal & 0.12 \\
\hline 19 & 26.12 & 1509 & Tridecanal & 1.01 \\
\hline 20 & 28.92 & 1529 & $\Gamma$-cadinene & 0.62 \\
\hline 21 & 29.47 & 1561 & Ledol & 8.24 \\
\hline 22 & 30.77 & 1604 & Viridiflorol & 4.61 \\
\hline 23 & 32.65 & 1615 & Tetradecanal & 0.31 \\
\hline 24 & 34.79 & 1663 & Caryophyllene & 1.77 \\
\hline 25 & 36.35 & 1715 & Farnesal & 0.52 \\
\hline 26 & 37.21 & 1766 & Tetradecanoic acid & 2.09 \\
\hline 27 & 38.89 & 1811 & Farnesoic acid & 0.85 \\
\hline 28 & 40.05 & 1847 & 6,10,14-trimethyl-2-pentadecanone & 21.43 \\
\hline 29 & 40.58 & 1883 & Farnesyl acetone & 2.03 \\
\hline 30 & 42.06 & 1980 & Hexadecanoic acid & 4.52 \\
\hline 31 & 43.98 & 2200 & Docosan & 2.76 \\
\hline 32 & 44.08 & 2300 & Tricosane & 0.81 \\
\hline
\end{tabular}


Romeilah RM et al. (2021). Not Bot Horti Agrobo 49(1):12233

\begin{tabular}{|c|c|c|c|c|}
\hline No. & RT & RI & Compound name & \% content \\
\hline 33 & 44.65 & 2400 & Tetracosane & 0.09 \\
\hline 34 & 45.76 & 2500 & Pentacosane & 0.11 \\
\hline 35 & 45.97 & 2600 & Hexacosane & 0.05 \\
\hline 36 & 46.32 & 2700 & Heptacosane & 0.16 \\
\hline 37 & 46.87 & 2800 & Octacosane & 0.04 \\
\hline \multicolumn{3}{|r|}{ Total identified } & 98.03 \\
\hline \multicolumn{3}{|c|}{ \% Essential oil yield } \\
\hline
\end{tabular}

$\mathrm{RT}=$ Retention time; RI= Retention index; Area sum \%; Values were expressed as [area percentage]

\section{Antioxidant activity}

Antioxidants are ingredients that protect living cells from the impairment created by unstable molecules called free radicals. Advantages of this antioxidant are necessary for conditions of free radicals, to function and to strengthen free radicals. Free radical damage can lead to the development of cancer (El-Beltagi et al., 2018). A molecule of antioxidants may prevent the oxidation or retardation of other molecule production. Oxidation covers chemical reaction in which electrons are transferred from the one substance to another. Free radicals are created by oxidation reactions that cause chain reactions that damage cells. Antioxidants limit these chain actions by eliminating free radical interim and decreasing other oxidation reactions (El-Beltagi et al., 2019a).The effect of antioxidants on DPPH radical scavenging and ABTS was thought to result from their hydrogen donating ability. In order to become stable diamagnetic molecule, DPPH is stable free radical and accepts an electron or hydrogen radical. In this study, the antioxidant activities of essential oils of $A$. monosperma and T. aphylla compared with ascorbic acid and butylated hydroxytoluene (BHT) as a reference antioxidant compound were determined by method of DPPH radical scavenging assay and ABTS assay and the results are summarized in Table 3 .

The scavenging of DPPH radicals and ABTS increased with increasing essential oil concentrations $\left(25,50,75,100\right.$ and $\left.200 \mu \mathrm{g} \mathrm{mL}^{-1}\right)$ (Table 3). The IC 50 value of DPPH radicals and ABTS of $A$. monosperma essential oil was 74.12 and $64.31 \mu \mathrm{g} \mathrm{mL} \mathrm{L}^{-1}$ concentration respectively. $\mathrm{IC}_{50}$ values indicate the concentration of test sample required to inhibit $50 \%$ of the free radicals. The high concentration of $A$. monosperma essential oil $\left(200 \mu \mathrm{g} \mathrm{mL}^{-1}\right)$ gave the highest \% inhibition of DPPH and ABTS about (91.96\% and $96.05 \%$ respectively).

In addition, scavenging of DPPH radicals and ABTS of $T$. aphylla essential oils were increased with increasing extract concentration from 25, 50, 75, 100 and $200 \mu \mathrm{g} \mathrm{mL}^{-1}$ (Table 3). The most pronounced increases in DPPH radicals and ABTS were detected in the high concentrations of oil $\left(200 \mu \mathrm{g} \mathrm{mL}^{-1}\right)$ about $27.32 \%$ and $83.03 \%$ respectively. IC 50 value of DPPH radicals and ABTS of T. aphylla essential oils was 134.9 and $109.23 \mu \mathrm{g} \mathrm{mL} \mathrm{m}^{-1}$ concentration respectively.

$\mathrm{IC}_{50}$ values indicated that antioxidant activity of $A$. monosperma essential oil was higher than $T$. aphylla essential oil. The high antioxidant activity of $A$. monosperma essential oil in this study may be due to presence of bornyl acetate $(7.63 \%)$ and $\alpha$-pinene (3.98\%) which considered as good antioxidant. These results are in accordance with Horváthováa et al. (2009) who found that $A$. monosperma essential oil contain both borneol and bornyl acetate, which are considered as major contributors in antioxidant activity of essential oils. In addition, $A$. monosperma showed high ratios of $\alpha$-pinene and terpinen-4-ol which are known to have noticeable antioxidant activities (Elansary et al., 2012). In T. aphylla, the main identified volatile principle, 6,10,14-trimethyl-2-pentadecanone, is a nonaromatic oxygenated hydrocarbon (ketone) and has slightly fatty aroma with reported antimicrobial (Iyapparaj et al., 2014) and antioxidant (Xu et al., 2016) properties. Also, the radical scavenging effect of $T$. aphylla bark extract from Saudi Arabia, which had a greater quantity of total phenolic compounds and also determined to be stronger in DPPH and $\mathrm{H}_{2} \mathrm{O}_{2}$ assays (Suleiman, 2019). 
Table 3. Antioxidant activities of $A$. monosperma and $T$. aphylla essential oils as well as ascorbic acid against $\mathrm{DPPH}^{\bullet}$ and $\mathrm{ABTS}^{\bullet+}$ at different concentrations

\begin{tabular}{|c|c|c|c|c|c|}
\hline \multirow[b]{2}{*}{ Treatment } & \multirow{2}{*}{$\begin{array}{c}\text { Concentration of essential } \\
\text { oil } \\
\left(\mu \mathrm{g} \mathrm{mL}^{-1}\right)\end{array}$} & \multicolumn{2}{|c|}{ DPPH assay } & \multicolumn{2}{|c|}{ ABTS assay } \\
\hline & & $\begin{array}{c}\text { \% Inhibition of } \\
\text { DPPH }^{\bullet}\end{array}$ & $\mathrm{IC}_{50}\left(\mu \mathrm{g} \mathrm{mL}^{-1}\right)$ & $\begin{array}{c}\text { \% Inhibition of } \\
\text { ABTS }^{*+}\end{array}$ & $\mathrm{IC}_{50}\left(\mu \mathrm{g} \mathrm{mL}^{-1}\right)$ \\
\hline \multirow{5}{*}{ A. monosperma } & 25 & $13.51^{\mathrm{ij}} \pm 3.16$ & \multirow{5}{*}{74.12} & $19.17^{\mathrm{h}} \pm 1.21$ & \multirow{5}{*}{64.31} \\
\hline & 50 & $25.43^{\mathrm{gh}} \pm 2.29$ & & $39.21^{f} \pm 3.42$ & \\
\hline & 75 & $50.24^{\mathrm{e}} \pm 2.03$ & & $66.54^{\mathrm{d}} \pm 1.92$ & \\
\hline & 100 & $62.92^{\mathrm{d}} \pm 2.39$ & & $82.36^{c} \pm 2.26$ & \\
\hline & 200 & $91.96^{b} \pm 2.23$ & & $96.05^{\mathrm{ab}} \pm 1.17$ & \\
\hline \multirow{5}{*}{ T. aphylla } & 25 & $9.94^{\mathrm{j}} \pm 2.01$ & \multirow{5}{*}{134.90} & $14.68^{\mathrm{h}} \pm 3.49$ & \multirow{5}{*}{109.23} \\
\hline & 50 & $20.06^{\mathrm{hi}} \pm 1.31$ & & $27.18^{\mathrm{g}} \pm 3.31$ & \\
\hline & 75 & $30.17^{g} \pm 1.94$ & & $39.87^{\mathrm{f}} \pm 0.58$ & \\
\hline & 100 & $38.29^{\mathrm{f}} \pm 2.44$ & & $48.48^{\mathrm{e}} \pm 0.44$ & \\
\hline & 200 & $72.32^{c} \pm 2.82$ & & $83.03^{c} \pm 1.39$ & \\
\hline \multirow{5}{*}{ Ascorbic acid } & 5 & $13.50^{\mathrm{ij}} \pm 2.16$ & \multirow{5}{*}{29.35} & $26.31^{\mathrm{g}} \pm 1.95$ & \multirow{5}{*}{20.41} \\
\hline & 10 & $27.66^{\mathrm{g}} \pm 1.83$ & & $39.36^{\mathrm{f}} \pm 2.02$ & \\
\hline & 20 & $38.89^{f} \pm 1.53$ & & $49.39^{\mathrm{e}} \pm 0.90$ & \\
\hline & 40 & $61.04^{\mathrm{d}} \pm 3.53$ & & $91.88^{\mathrm{b}} \pm 0.90$ & \\
\hline & 60 & $92.96^{b} \pm 2.03$ & & $100.00^{a} \pm 0.00$ & \\
\hline \multirow{5}{*}{ ВНT } & 5 & $22.08^{\mathrm{gh}} \pm 1.81$ & \multirow{5}{*}{18.12} & $36.34^{\mathrm{f}} \pm 0.64$ & \multirow{5}{*}{9.93} \\
\hline & 10 & $35.93^{f} \pm 3.08$ & & $51.18^{\mathrm{e}} \pm 1.36$ & \\
\hline & 20 & $62.21^{\mathrm{d}} \pm 1.64$ & & $97.55^{a} \pm 0.83$ & \\
\hline & 40 & $93.43^{\mathrm{ab}} \pm 1.67$ & & $100^{a} \pm 0.00$ & \\
\hline & 60 & $100^{\mathrm{a}} \pm 0.00$ & & $100^{a} \pm 0.00$ & \\
\hline \multicolumn{2}{|c|}{ LSD 0.05} & 6.63 & & 5.00 & \\
\hline
\end{tabular}

- Each value represents the mean \pm SE.

- Means in the same column followed by the same letter are not significantly different at $(\mathrm{P}<0.05)$.

\section{Cytotoxic effect}

The cytotoxic activity of $A$. monosperma and T. aphylla essential oils were tested in vitro against human promyelocytic leukaemia cell lines (HL60 and NB4) using viability test. Viability percentage of HL60 and NB4 cells after incubation with different concentrations of $A$. monosperma and $T$. aphylla essential oils $(25,50,75$, 100 and $200 \mu \mathrm{g} \mathrm{mL}^{-1}$ ) were recorded in Table 4. Data showed that the incubation of cancer cells with different concentrations $\left(25,50,75,100\right.$ and $\left.200 \mu \mathrm{g} \mathrm{mL}^{-1}\right)$ for $24 \mathrm{~h}$ of A. monosperma and T. aphylla essential oils significantly reduced viability of those cells when compared to untreated cells (control). The dead cells (HL60 and NB4) were significantly increased with increasing essential oils concentrations. The results showed that, anticancer effects of $A$. monosperma and $T$. aphylla essential oils on NB4 cells were more than anticancer effects on HL-60 cells.

On the other side, anticancer effects of $A$. monosperma essential oil on HL-60 and NB4 cells were more than anticancer effects of $T$. aphylla essential oil. The highest dead cells percentage of HL-60 was recorded $A$. monosperma and T. aphylla essential oils (92.76\% and 56.08\%) respectively, for concentration of $200 \mu \mathrm{g} \mathrm{mL}$ ${ }^{1}$. In the same trend, the highest dead cells percentage of NB4 was recorded by $A$. monosperma and T. aphylla essential oils (100\% and 68.25\%) respectively, for concentration of $200 \mu \mathrm{g} \mathrm{mL}^{-1}$. A. monosperma essential oil showed potent cytotoxic effects with IC 50 values of $93.39 \mu \mathrm{g} \mathrm{mL}^{-1}$ in HL-60 cell line and $55.73 \mu \mathrm{g} \mathrm{mL}^{-1}$ in NB4 cell line, whereas T. aphylla essential oil gave $\mathrm{IC}_{50}$ values of $164.62 \mu \mathrm{g} \mathrm{mL}^{-1}$ in HL-60 cell line and $84.83 \mu \mathrm{g} \mathrm{mL}$ ${ }^{1}$ in NB4 cell line. $\mathrm{IC}_{50}$ values indicated that anticancer activity of $A$. monosperma essential oil was higher than T. aphylla essential oil against HL-60 and NB4 cell lines.

Essential oil from aerial section of $A$. herba-alba collected at floral stage had greater cytotoxic effect on HUVEC cells than herba-alba collected at seed stage, with cell viability of $20 \%$ at $80 \mu \mathrm{M}$. (Jaouadi et al., 2014). Artemisia absinthium oil contains trans-caryophyllene, 3,6-dihydrochamazulene, and cisepoxyocimene as main compounds and showed cytotoxic activity against A549, HCT116, MCF7, H292, SK-MEL-5 and HS5 cells with the $\mathrm{IC}_{50}$ value of $51.1 \pm 1.8$ to $98.6 \pm 5.2 \mu \mathrm{g} / \mathrm{mL}$. Both of the obtained oils from aerial parts of $A$. persica and $A$. turcomanica contain $\beta$-thujone, 1,8-cineol, camphor, and filifolone as their main compounds, which 
exhibited a significant cytotoxic effect on MCF-7 cells with IC $_{50}$ value of 0.15 and $0.1 \mu \mathrm{g} / \mathrm{mL}$, respectively (Nikbakht et al., 2014). Essential oil of $A$. indica contains germacrene $\mathrm{B}$, artemisia ketone, borneol, and cischrysanthenyl acetate as main constituents, which demonstrated cytotoxic activity with $\mathrm{IC}_{50}$ values of 10 to $19.5 \mu \mathrm{g} / \mathrm{mL}$ against THP-1, HEP-2, A-549 and Caco-2 cancer cell lines (Rashid et al., 2013). The essential oil of $A$. scoparia contains iacetylenes 1-phenyl-2,4-pentadiyne, capillene, $\beta$-pinene, methyl eugenol as major components and was inactive against MCF-7 cells (Sharopov and Setzer, 2011). Artemisia dubia leaves oil contains chrysanthenone, coumarin, and camphor as major components at concentration of $100 \mu \mathrm{g} / \mathrm{mL}$, which completely killed MCF- 7 cells (Satyal et al., 2012).

Table 4. Cytotoxic effect of $A$. monosperma and T. aphylla essential oils on the viability of HL-60 and NB4 cells

\begin{tabular}{|c|c|c|c|c|c|c|c|}
\hline \multirow[b]{2}{*}{ Treatment } & \multirow{2}{*}{$\begin{array}{l}\text { Concentration } \\
\text { of essential oil } \\
\quad\left(\mu \mathrm{g} \mathrm{mL}^{-1}\right)\end{array}$} & \multicolumn{3}{|c|}{ HL-60 cells } & \multicolumn{3}{|c|}{ NB4 cells } \\
\hline & & $\begin{array}{c}\% \text { of dead } \\
\text { cells }\end{array}$ & $\begin{array}{c}\% \text { of viable } \\
\text { cells }\end{array}$ & $\begin{array}{c}\mathrm{IC}_{50} \\
\left(\mu \mathrm{g} \mathrm{mL} L^{-1}\right)\end{array}$ & $\begin{array}{c}\% \text { of dead } \\
\text { cells }\end{array}$ & $\begin{array}{c}\% \text { of viable } \\
\text { cells }\end{array}$ & $\begin{array}{c}\mathrm{IC}_{50} \\
\left(\mu \mathrm{g} \cdot \mathrm{mL}^{-1}\right)\end{array}$ \\
\hline Control & 0 & 0 & 100 & & 0 & 100 & \\
\hline \multirow{5}{*}{$\begin{array}{c}A . \\
\text { monosperm } \\
a\end{array}$} & 25 & $13.08^{f} \pm 2.55$ & 86.92 & \multirow{5}{*}{93.39} & $29.04^{\mathrm{fg}} \pm 2.16$ & 70.96 & \multirow{5}{*}{55.73} \\
\hline & 50 & $25.51^{\mathrm{e}} \pm 1.98$ & 74.49 & & $37.90^{\mathrm{e}} \pm 1.76$ & 62.10 & \\
\hline & 75 & $43.08^{d} \pm 3.02$ & 56.92 & & $66.12^{c} \pm 2.67$ & 33.88 & \\
\hline & 100 & $67.90^{b} \pm 2.95$ & 32.10 & & $87.11^{b} \pm 2.02$ & 12.89 & \\
\hline & 200 & $92.67^{a} \pm 0.85$ & 7.33 & & $100^{\mathrm{a}} \pm 0.00$ & 0.00 & \\
\hline \multirow{5}{*}{ T. aphylla } & 25 & $4.00 \mathrm{~g} \pm 0.58$ & 96.00 & \multirow{5}{*}{164.62} & $25.06^{\mathrm{g}} \pm 2.16$ & 74.94 & \multirow{5}{*}{84.83} \\
\hline & 50 & $16.59^{f} \pm 2.42$ & 83.41 & & $35.50^{\text {ef }} \pm 2.59$ & 64.50 & \\
\hline & 75 & $27.49^{\mathrm{e}} \pm 1.08$ & 72.51 & & $41.42^{\mathrm{e}} \pm 4.35$ & 58.58 & \\
\hline & 100 & $38.65^{\mathrm{d}} \pm 1.90$ & 61.35 & & $55.44^{\mathrm{d}} \pm 4.46$ & 44.56 & \\
\hline & 200 & $56.08^{c} \pm 1.53$ & 43.92 & & $68.25^{\mathrm{c}} \pm 1.09$ & 31.75 & \\
\hline LSD $_{0.05}$ & & 6.07 & & & 7.82 & & \\
\hline
\end{tabular}

Similar results showed that aqueous and ethanolic extract of $T$. aphylla had potent cytotoxic activity against some cancer cell line specially MCF-7 cell line with $\mathrm{IC}_{50}$ values (Yusufoglu and Al-qasoumi, 2011). Also, essential oils were extracted from aerial parts of Tamarix aphylla L., a wild plant in Jordan. Aqueous (AE) and ethanolic (EE) extracts were prepared from $T$. aphylla and their cytotoxicity against breast adenocarcinoma (MCF-7), colorectal adenocarcinoma (Caco-2), and pancreatic carcinoma (Panc-1) cancer cell lines was evaluated. The lowest $\mathrm{IC}_{50}\left(2.17 \pm 0.10 \mu \mathrm{g} \mathrm{mL}^{-1}\right)$ was recorded for the AE of T.aphylla against MCF-7, they found that T.aphylla has antitumor activity comparable with cisplatin however, more selective to cancer cells since its $\mathrm{IC}_{50}$ against fibroblast was $79.99 \pm 4.90 \mu \mathrm{g} \mathrm{mL}^{-1}$ (Alhourani et al., 2018). In addition, T. aphylla leaf extracts inhibited the proliferation of MCF-7 cells in a dose-dependent manner with significant cytotoxic effect at $24 \mathrm{~h}$ with a concentration of $50 \mathrm{mg} \mathrm{mL}^{-1}$. MCF-7 cells in this study were exhibited anticancer activities in the concentration-dependent manner at 500 and $1000 \mu \mathrm{g} \mathrm{mL}^{-1}$ (Al Sobeai, 2018). Moreover, recent study on methanol extract of $T$. aphylla had investigated its potential cytotoxicity using brine shrimp method and revealed $70 \%$ mortality rate at concentration of $500 \mu \mathrm{g} \mathrm{mL}^{-1}$ (Muhammad et al., 2017).

The essential oil and their constituents target multiple pathways in cancer cells was reported by Gautam et al. (2014) who demonstrated that, essential oils (EOs) are permeable and participate in different pathways involving cellular targets with respect to their cell membrane permeability. The EO's increase intracellular level, or those in reactive nitrogen cells the reactive (ROS/RNS) which generates apoptosis in cancer cells. Inhibition of protein Kinase B (Akt), mammalian target of rapamycin (Mtor) and Mitogen-Activated Protein Kinases (MAPK) pathways at different steps by EOs leads to corresponding up-/down regulation of various key biomolecules and corresponding genes. Alteration in expression of Nuclear factor kappa-light- chain-enhancer of activated B cells (NF-KB) by EOs and further binding of NF-KB to DNA result in apoptosis in cancer cells. Akt dephosphorylation results in overexpression of $\mathrm{p} 21$ through action of EOs, which either causes apoptosis by increasing amount of caspases or results in cell cycle arrest by binding to cyclines. In addition, mitochondrial 
stress caused by EOs leads to activation of Bcl-2 gene and depolarisation of membrane, resulting in increased release of cytochrome-C to cytoplasm, causing apoptotic cell death in cancer cells. The EOs also modulate DNA repair mechanisms by acting as DNA polymerase inhibitors and lead to poly (ADP-Ribose) polymerase (PARP) cleavage which also results in apoptosis in cancer cells.

\section{Conclusions}

From the data presented in the current stud, can be concluded that the A. monosperma and T. aphylla that is widely dispersed in the deserts of Saudi Arabia has a different chemotype and can be used as a cheap source for the commercial isolation of $\beta$-pinene, $\alpha$-terpinolene, 6,10,14-trimethyl-2-pentadecanone, 1,8cineole and limonene. Moreover, the detailed chemical profiling of the volatile components of the leaf of $A$. monosperma and aerial parts of $T$. aphylla essential oils in the present study could be useful in the chemotaxonomic classification of the Artemisia and Tamarix species that grow wild in the agro-climatic conditions of Saudi Arabia. These findings of antioxidant activities enhanced the capacity of $A$. monosperma and $T$. aphylla extracts in the reported traditional medicinal uses and suggest that these plants may be considered potential sources of new antioxidant drugs.

\section{Authors' Contributions}

Conceptualization: R.M.R., H.S.E. and E.A.S.; Data curation: K.M.Y., H.E. and S.R.; Formal analysis: R.M.R., K.M.Y., H.E. and S.R.; Funding acquisition: R.M.R. and E.A.S.; Investigation: R.M.R., H.S.E., E.A.S. and H.I. M.; Methodology: R.M.R., E.A.S. and H.S.E; Project administration: R.M.R., E.A.S. and H.S.E; Resources: R.M.R., K.M.Y., H.E. and S.R.; Software: R.M.R., and H.S.E; Supervision: R.M.R., H.S.E. and E.A.S.; Writing-original draft preparation: H.S.E. and H.I.M.; writing-review and editing, H.S.E. and H.I.M All authors read and approved the final manuscript.

\section{Acknowledgements}

This research has been funded by Scientific Research Deanship at University of Ha'il - Saudi Arabia through project number RG-191256.

\section{Conflict of Interests}

The authors declare that there are no conflicts of interest related to this article.

\section{References}

Abad MJ, Bedoya LM, Apaza L, Bermejo P (2012). The Artemisia L. genus: A review of bioactive essential oils. Molecules 17:2542-2566.

Abd El-Maksoud AA, Abd El-Ghany IH, El-Beltagi HS, Anankanbil S, Banerijee C, Petersen SV, ... Guo Z (2018). Adding functionality to milk-based protein: Preparation, and physicochemical characterization of $\beta$ $\begin{array}{llll}\text { lactoglobulinphenolic } & \text { conjugates. } & \text { Food 241:281-289. }\end{array}$ https://doi.org10.1016/j.foodchem.2017.08.101 
Abdel-Rahim EA, El-Beltagi HS (2010). Constituents of apple, parsley and lentil edible plants and their therapy treatments for blood picture as well as liver and kidney functions against lipidemic disease. Electronic Journal of Environmental, Agricultural and Food Chemistry 9(6):1117-1127.

Abd El- Rahman SS, Mazen MM, Mohamed HI, Mahmoud NM (2012). Induction of defense related enzymes and phenolic compounds in lupine (Lupinus albus L.) and their effects on host resistance against Fusarium wilt. European Journal of Plant Pathology 134:105-116. https://doi.10.1007/s10658-012-0028-Z

Afify AEMM, El-Beltagi HS (2011). Effect of insecticide cyanophos on liver function in adult male rats. Fresenius Environmental Bulletin 20(4a):1084-1088 .

Afify AEMM, El-Beltagi HS, Aly AA, El-Ansary AE (2012). Antioxidant enzyme activities and lipid peroxidation as biomarker for potato tuber stored by two essential oils Caraway and Clove and its main component Carvone and Eugenol. Asian Pacific Journal of Tropical Biomedicine 2:S772-S780.

https://doi.org/10.1016/S2221-1691(12)60312-8

Adams RP (1989). Identification of essential oils by ion trap mass spectroscopy. Academic press, New York.

Akladious SA, Mohamed HI (2017). Physiological role of exogenous nitric oxide in improving performance, yield and some biochemical aspects of sunflower plant under zinc stress. Acta Biologica Hungarica 68(1):101-114. https://doi.org/10.1556/018.68.2017.1.9

Al Sobeai SM (2018). Anticancer, cytotoxic effect of Tamarix aphylla, and antibacterial screening efficiency against multidrug-resistant human pathogens. Asian Journal of Pharmaceutical and Clinical Research 11(11):241-246. https://doi.org/10.22159/ajpcr.2018.v11i11.27309

Alhourani N, Kasabri V, Bustanji Y, Abbassi R, Hudaib M. (2018). Potential antiproliferative activity and evaluation of essential oil composition of the aerial parts of Tamarix aphylla (L.) H. Karst.: a wild grown medicinal plant in Jordan. Evidence-Based Complementary and Alternative Medicine 2018:7. https://doi.org/10.1155/2018/9363868

Aly AA, Mohamed HI, Mansour MTM, Omar MR (2013) Suppression of powdery mildew on flax by foliar application of essential oils. Journal of Phytopatholology 161:376-381. https://doi.org/10.1111/jph.12080

Apostolova N, Victor VM (2015). Molecular strategies for targeting antioxidants to mitochondria: therapeutic implications. Antioxidants \& Redox Signaling 22(8):686-729. https://doi.org/10.1089/ars.2014.5952

Bae I, Song J-A, Lee M, Hur M (2018). Effects of aromatherapy essential oil inhalation on the stress response after exposure to noise and arithmetic subtraction stressor: randomized controlled trial. International Journal of Clinical and Experimental Medicine 11(1):275-284.

Bennett JM, Catovsky D, Danniel MT, Galton DAG, Graanlnik HR, Sultan C (1976). Proposal for the classification of the acute leukemias. British Journal of Haematology 33:451-458. https://doi.org/10.1111/j.1365-2141.1976.tb03563.x

Bora KS, Sharma A (2011). The genus Artemisia: A comprehensive review. Pharmaceutical Biology 49:101-109. https://doi.org/10.3109/13880209.2010.497815

Brand-Williams W, Cuvelier ME, Berset C (1995). Use of a free radical method to evaluate antioxidant activity. LWTFood Science and Technology 28:25-30. https://doi.org/10.1016/S0023-6438(95)80008-5

Dawi F, El-Beltagi HS, Abdel-Mobdy YE, Salah SM, Ghaly IS, Abdel-Rahim EA, Mohamed HI, Soliman AM (2021). Synergistic impact of the pomegranate peels and its nanoparticles against the infection of tobacco mosaic virus (TMV). Fresenius Environmental Bulletin 30(1):731-746.

Dhif W, Bellili S, Jazi S, Bahloul N, Mnif W (2016). Essential oils' chemical characterization and investigation of some biological activities: a critical review. Medicines 3(4):25-31. https://doi.org/10.3390/medicines3040025

El Ansari M A., Nawwar MAM, El Dein A, El Sherbeiny A, El Sissi HI (1976). A sulphated kaempferol 7,4-dimethyl ether and a quercetin isoferulylglucuronide from the flowers of Tamarix aphylla. Phytochemistry 15(1):231-232.

Elansary HO, Salem MZM, Ashmawy NA, Yacout M (2012). Chemical composition, antimicrobial and antioxidant activities of Lantana camara, Cupressus sempervirens and Syzygium cumini leaves oils from Egypt. Journal of Agricultural Science 4:144-52. https://doi.org/10.5539/jas.v4n10p144

El-Beltagi HS, Ahmed SH, Namich AAM, Abdel-Sattar RR (2017). Effect of salicylic acid and potassium citrate on cotton plant under salt stress. Fresenius Environmental Bulletin 26(1a):1091-1100

El-Beltagi HS, Mohamed HI, Safwat G, Megahed BMH, Gamal M (2018). Evaluation of some chemical constituents, antioxidant, antibacterial and anticancer activities of Beta vulgaris L. root. Fresenius Environmental Bulletin 27(9):6369-6378. 
El-Beltagi HS, Mohamed HI, Elmelegy AA, Eldesoky SE, Safwat G (2019a). Phytochemical screening, antimicrobial, antioxidant, anticancer activities and nutritional values of cactus (Opuntia ficus indicia) pulp and peel. Fresenius Environmental Bulletin 28(2A):1534-1551.

El-Beltagi HS, Mohamed HI, Safwat G, Gamal M, Megahed BMH (2019b). Chemical composition and biological activity of Physalis peruviana L. Gesunde Pflanzen 71:113-122. https://doi.org/10.1007/s10343-019-00456-8

El-Beltagi HS, Mohamed HI, Sofy MR (2020). Role of ascorbic acid, glutathione and proline applied as singly or in sequence combination in improving chickpea plant through physiological change and antioxidant defense under different levels of irrigation intervals. Molecules 25:1702. https://doi.org/10.3390/molecules25071702

El-Beltagi HS, Sofy MR, Aldaej MI, Mohamed HI (2020). Silicon alleviates copper toxicity in flax plants by up-regulating antioxidant defense and secondary metabolites and decreasing oxidative damage. Sustainability 12:4732. https://doi.org/10.3390/su12114732

European Pharmacopoeia (2005). Council of Europe. Fifth ed., vol. 2 Strasbourg, pp 2710-2711.

Fabri RL, Nogueira MS, Dutra LB, Bouzada MLM, Scio E (2011). Potencial antioxidante e antimicrobiano de espécies da família Asteraceae. Revista Brasileira de Plantas Medicinais 13:183-189. http://dx.doi.org/10.1590/S1516-05722011000200009.

Gautam N, Mantha AK, Mittal S (2014). Essential oils and their constituents as anticancer agents: A mechanistic view. BioMed Research International http://dx.doi.org/10.1155/2014/154106

Guetat A, Al-Ghamdi FA, Osman AK (2017). The genus Artemisia L. in the northern region of Saudi Arabia: essential oil variability and antibacterial activities. Natural Product Research 31(5):598-603. https://doi.org/10.1080/14786419.2016.1207071

Guo S, Ge Y, Jom KN (2017). A review of phytochemistry, metabolite changes, and medicinal uses of the common sunflower seed and sprouts (Helianthus annuus L.). Chemistry Central Journal 11(1):95101. https://doi.org/10.1186/s13065-017-0328-7

Hamed MM, Abd El-Mobdy MA, Kamel MT, Mohamed HI, Bayoumi AE (2019). Phytochemical and biological activities of two asteraceae plants Senecio vulgaris and Pluchea dioscoridis L. PharmacologyOnline 2:101-121. https://doi.org/10.1055/s-0035-1565700

Helmi A, Mohamed HI (2016). Biochemical and ulturasturctural changes of some tomato cultivars to infestation with Aphis gossypii Glover (Hemiptera: Aphididae) at Qalyubiya, Egypt. Gesunde Pflanzen 68:41-50. https://doi.org/10.1007\%2Fs10343-016-0361-9

Horváthováa E, Slamenováa D, Maršálkováa L, Šramkováa M, W sólováb L (2009). Effects of borneol on the level of DNA damage induced in primary rat hepatocytes and testicular cells by hydrogen peroxide. Food and Chemical Toxicology 47:1318-23. https://doi.org/10.1016/j.fct.2009.03.002

Iyapparaj P, Revathi P, Ramasubburayan R, Prakash S, Palavesam A, Immanuel G, ... Hellio C (2014). Antifouling and toxic properties of the bioactive metabolites from the seagrasses Syringodium isoetifolium and Cymodocea $\begin{array}{llll}\text { serrulata. Ecotoxicology and } & \text { Environmental }\end{array}$ https://doi.org/10.1016/j.ecoenv.2014.02.009

Jaouadi I, Koparal AT, Bostancioglu RB, Yakoubi MT, El Gazzah M (2014). The anti-angiogenic activity of Artemisia herba-alba's essential oil and its relation with the harvest period. Australian Journal of Crop Science 8:13951401.

Jasiem TM, Nasser NM, Al-Bazaz HK (2019). Tamarix aphyllaL: a review. Research Journal of Pharmacy and Technology 12(7):3219-3222. https://doi.org/10.5958/0974-360X.2019.00541.9

Khan M, Mousa AA, Syamasundar KV, Alkhathlan HZ (2012). Determination of chemical constituents of leaf and stem essential oils of Artemisia monosperma from central Saudi Arabia. Natural Product Communication 7:10791082. https://doi.org/10.1177/1934578X1200700829

Klocke JA, VanWagenent B, Balandrin MF (1985). The ellagitannin geraniin and its hydrolysis products isolated as insect growth inhibitors from semi-arid land plants. Phytochemistry 25(1):85-91. https://doi.org/10.1016/S00319422(00)94507-2

Maham M, Moslemzadeh H, Jalilzadeh-Amin G (2014). Antinociceptive effect of the essential oil of tarragon (Artemisia dracunculus). Pharmacutical Biology 52:208-212. https://doi.org/10.3109/13880209.2013.824007

Mahemuti M, Miliban H, Mearhaba W (2015). Analysis of volatile oil and fatty acids in Tamarix chinensis fruit. Chinese Journal of Applied Chemistry 2:239-244. https://doi.org/10.11944/j.issn.1000-0518.2015.02.140136 
Mahfoudhi A, Grosso C, Gonçalves RF, Khelifi E, Hammami S, Achour S, ... Mighri Z (2016). Evaluation of antioxidant, anti-cholinesterase, and antidiabetic potential of dry leaves and stems in Tamarix aphylla growing wild in Tunisia. Chemistry Biodiversity 12:1747-1755. https://doi.org/10.1002/cbdv.201600157

Malik T (2018). Perspective uses of essential oils in functional foods and antimicrobial packaging material. In: Food Science and Nutrition: Breakthroughs in Research and Practice. Edited by Information Resources Management Association, pp 235-265. https://doi.org/10.4018/978-1-5225-5207-9.ch012

Ahmad M, Zafar M, Sultana S (2009). Salvadora persica, Tamarix aphylla and Zizyphus mauritiana - three woody plant species mentioned in Holy Quran and Ahadith and their ethnobotanical uses in north western part (DI Khan) of Pakistan. Pakistan Journal of Nutrition 8(5):542-547. https://doi.org/10.3923/pjn.2009.542.547

Mohamed AA, El-Beltagi HS, Rashed MM (2009). Cadmium stress induced change in some hydrolytic enzymes, free radical formation and ultrastructural disorders in radish plant. Electronic Journal of Environmental, Agricultural and Food Chemistry 8(10):969-983.

Mohamed HI, Akladious SA, El-Beltagi HS (2018a). Mitigation the harmful effect of salt stress on physiological, biochemical and anatomical traits by foliar spray with trehalose on wheat cultivars. Fresenius Environmental Bulletin 27(10):7054-7065.

Mohamed H.I, El-Beltagi HS, Aly AA, Latif HH (2018b). The role of systemic and non systemic fungicides on the physiological and biochemical parameters in Gossypium hirsutum plant, implications for defense responses. Fresenius Environmental Bulletin 27(12):8585-8593.

Muhammad H, Wazir SM, Khan RA (2017). In vitro antioxidant, antifungal and cytotoxic activities of selected medicinal plants of District Bannu and Lakki Marwat. Studies on Ethno-Medicine 11:226-232. https://doi.org/10.1080/09735070.2017.1322368

Nawwar MAM, Hussein SAM, Ayoub NA, Hofmann K, Linscheid M, Harms M, ... Lindequist U (2009). Aphyllin, the first isoferulic acid glycoside and other phenolics from Tamarix aphylla flowers. Die Pharmazie 64(5):342-347. https://doi.org/10.1002/chin.200937206

Nikbakht M, Sharifi S, Emami S, Khodaie L (2014). Chemical composition and antiprolifrative activity of Artemisia persica Boiss. and Artemisia turcomanica Gand. essential oils. Research in Pharmaceutical Sciences 9:155.

Orabi MAA, Yoshimura M, Amakura Y, Hatano T (2015). Ellagitannins, gallotannins, and gallo-ellagitannins from the galls of Tamarix aphylla. Fitoterapia 104:55-63. https://doi.org/10.1016/j.fitote.2015.05.008

Orfali RS (2009). Phytochemical and biological study of Tamarix nilotica growing in Saudi Arabia. Thesis, College of Pharmacy, King Saud University, Saudi Arabia.

Pandey AK, Tripathi NN (2011). Aromatic plants of Gorakhpur forest division: Their antimycotic property and medicinal value. International Journal of Pharmaceutical Sciences Review and Research 7:142-147.

Qadir MI, Abbas K, Hamayun R, Ali M (2014). Analgesic, anti-inflammatory and anti-pyretic activities of aqueous ethanolic extract of Tamarix aphylla L. (Saltcedar) in mice. Pakistan Journal of Pharmaceutical Sciences 27(6):1985-1988.

Rashid S, Rather MA, Shah WA, Bhat BA (2013). Chemical composition, antimicrobial, cytotoxic and antioxidant activities of the essential oil of Artemisia indica Willd. Food Chemistry 138:693-700. https://doi.org/10.1016/j.foodchem.2012.10.102

Re R, Pellegrini N, Proteggente A, Pannala A, Yang M, Rice-Evans C (1999). Antioxidant activity applying an improved ABTS radical cation decolorization assay. Free Radical Biology and Medicine 26:1231-1237. https://doi.org/10.1016/S0891-5849(98)00315-3

Reis JF, Monteiro VVS, de Souza Gomes R, do Carmo MM, da Costa GV, Ribera PC, Monteiro MC (2016). Action mechanism and cardiovascular effect of anthocyanins: a systematic review of animal and human studies. Journal of Translational Medicine 14:315-322. https://doi.org/10.1186/s12967-016-1076-5

Saidana D, Mahjoub MA, Boussaada O, Chriaa J, Chéraif I, Daami M, ... Helal AN (2008). Chemical composition and antimicrobial activity of volatile compounds of Tamarix boveana (Tamaricaceae). Microbiological Research 163(4):445-455. https://doi.org/10.1016/j.micres.2006.07.009

Saleh MA. (1985). Volatile components of Artemisia monosperma and A. judaica growing in the Egyptian deserts. Biochemical Systematics and Ecology 13:265-269. https://doi.org/10.1016/0305-1978(85)90037-7

Satyal P, Paudel P, Kafle A, Pokharel SK, Lamichhane B, Dosoky NS, ... Setzer WN (2012). Bioactivities of volatile components from Nepalese Artemisia species. Natural Products Communications 7:1651-1658. https://doi.org/10.1177/1934578X1200701228 
Shallan MA, El-Beltagi HS. Mona AM, Amera TM, Sohir NA (2010a). Effect of am-ylose content and pre-germinated brown rice on serum blood glucose and lipids in experimental animal. Australian Journal of Basic and Applied Scieces 4(2):114-121.

Shallan MA, El-Beltagi HS, Mona AM, Amera TM (2010b). Chemical evaluation of pre-germinated brown rice and whole grain rice bread. Electronic Journal of Environmental, Agricultural and Food Chemistry 9(5):958-971.

Sharopov FS, Setzer WN (2011). The essential oil of Artemisia scoparia from Tajikistan is dominated by phenyldiacetylenes. Natural Product Communications 6:119-122.

Sikka SC, Bartolome AR (2018). Perfumery, essential oils, and household chemicals afecting reproductive and sexual health. In: Bioenvironmental issues afecting men's reproductive and sexual health, Elsevier, Amsterdam, Netherlands, pp 557-569.

Singh P, Sonker N, Pandey AK (2015). Chemical composition and antioxidant activity of essential oil of Artemisia nilagirica from Eastern Uttar Pradesh, India. Journal of Essential Oil Bearing Plants 18:734-738. https://doi.org/10.1080/0972060X.2014.960267

Soliman MMM (2007). Phytochemical and toxicological studies of Artemisia L. (Compositae) essential oil against some insect pests. Archives of Phytopathology and Plant Protection 40:128-138. https://doi.org/10.1080/03235400500355808

Souliman AMA, Barakat HH, El-Mousallamy AMD, Marzouk MSA, Nawwar MAM (1991). Phenolics from the bark of Tamarix aphylla. Phytochemistry 30(11):3763-3766. https://doi.org/10.1016/0031-9422(91)80105-A

Suleiman MHA (2019). Ethnobotanical, phytochemical, and biological study of Tamarix aphylla and Aerva javanica medicinal plants growing in the Asir region, Saudi Arabia. Tropical Conservation Science 12:1-14. https://doi.org/10.1177/1940082919869480

Xu C, Zhao S, Li M, Dai Y, Tan L, Liu Y (2016). Chemical composition, antimicrobial and antioxidant activities of essential oil from flue-cured tobacco flower bud. Biotechnology \& Biotechnological Equipment 30(5):10261030. https://doi.org/10.1080/13102818.2016.1195240

Yen GC, Duh PD (1994). Scavenging effect of methanolic extracts of peanut hulls on free-radical and active-oxygen species. Journal of Agriculture and Food Chemistry 42:629-632. https://doi.org/10.1021/jf00039a005

Yusufoglu HS, Alqasoumi SI (2011). Anti-inflammatory and wound healing activities of herbal gel containing an antioxidant Tamarix aphylla leaf extract. International Journal of Pharmacology 7(8):829-835. https://doi.org/10.3923/ijp.2011.829.835

Yusufoglu HS, Alam A, Al-Howeemel A (2015). Pharmacognostic and preliminary phytochemical standardization of Tamarix aphylla and Ziziphus nummularia growing in Saudi Arabia. Asian Journal of Biological and Life Sciences 1:42-46.
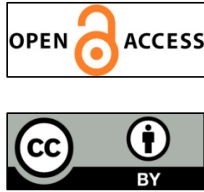

The journal offers free, immediate, and unrestricted access to peer-reviewed research and scholarly work. Users are allowed to read, download, copy, distribute, print, search, or link to the full texts of the articles, or use them for any other lawful purpose, without asking prior permission from the publisher or the author.

License - Articles published in Notulae Botanicae Horti Agrobotanici Cluj-Napoca are Open-Access, distributed under the terms and conditions of the Creative Commons Attribution (CC BY 4.0) License. (C) Articles by the authors; UASVM, Cluj-Napoca, Romania. The journal allows the author(s) to hold the copyright/to retain publishing rights without restriction. 